\title{
Supplemental Effects of Zinc Oxide on the Utilization of Cassava Plant Meal by Growing Pigs in the Humid Tropics
}

\author{
Emmanuel Oluropo Akinfala \\ Department of Animal Sciences, Obafemi Awolowo University, Ile-Ife 220005, Osun State, Nigeria
}

\begin{abstract}
The objective of this study was to evaluate the effects of zinc oxide $(\mathrm{ZnO})$ as an additive on cassava plant meal through the growth, serum metabolites and heamatological indices of growing pigs for eight weeks. Four experimental diets were formulated in this study. All the four diets contained $60 \%$ cassava plant meal. Diet 1 contained 0 ppm of $\mathrm{ZnO}$, while diets 2,3 and 4 contained 125, 250 and $300 \mathrm{ppm}$ of $\mathrm{ZnO}$, respectively. The cassava plant meal contained unpeeled tuber plus leaves and tender stems. The unpeeled cassava tuber was mixed with leaves and tender stem at ratio 2.5:1, while the ratio of the leaves and tender stem was 5:1. A total of 16 growing pigs (Large White $\times$ Hampshire) with initial mean weight of $24.92 \pm 0.37 \mathrm{~kg}$ were used in this study. They were randomly distributed into the four experimental diets formulated. There were four animals per diet and each animal served as a replicate. The diets were formulated to contain about $19 \%$ crude protein and $2.5 \mathrm{kcal} / \mathrm{g}$ metabolizable energy. This experiment was completely randomized designed. The results of this study showed that weight gain, feed intake and feed conversion ratio were not significantly $(P \geq 0.05)$ affected by the inclusion of $\mathrm{ZnO}$, although numerically $250 \mathrm{ppm}$ gave the better values. The serum metabolites, such as the total protein, albumin, urea and cholesterol, were not significantly $(P \geq 0.05)$ affected by the inclusion of $\mathrm{ZnO}$. However, the serum creatinine and glucose were significantly $(P \leq 0.05)$ affected. Moreover, haematological indices, such as the packed cell volume (PCV), haemoglobin $(\mathrm{HB})$ and red blood cell (RBC), were not significantly $(P \geq 0.05)$ affected by the inclusion of $\mathrm{ZnO}$; while the white blood cell $(\mathrm{WBC})$ was significantly $(P \leq 0.05)$ affected. It can be concluded from this study that $\mathrm{ZnO}$ could be used as an additive to improve the utilization of cassava plant meal by growing pigs.
\end{abstract}

Key words: Cassava plant meal, $\mathrm{ZnO}$, diets, growing pigs.

\section{Introduction}

The use of cassava (flour, peels and leaves) as feedstuffs for livestock has been a continuous subject of investigation by animal nutritionists in Nigeria. Although there had been many studies by researchers [1-3] on the use of cassava for livestock feeding, which centered on the flour, peels or leaves. In most of these studies, cassava flour was found to be more economical to replace maize, especially in the diets of pig. But according to Akinfala and Matanmi [4], the price of cassava (flour) has been on the increase, because it has been attracting interest as an industrial crop in Nigeria, and various uses in the starch,

Corresponding author: Emmanuel Oluropo Akinfala, Ph.D., research field: monogastric animal nutrition. E-mail: akinfala@oauife.edu.ng; oakinfala@yahoo.com. pharmaceutical, bread and biscuit industries have been found. This has made the use of cassava flour to replace maize uneconomical, especially in the diets of pigs. Because of the positive effects of the inclusion of the various products of cassava in the diets of livestock, most importantly in pigs, attempt was made by Akinfala et al. [5] to develop a composite cassava plant meal from unpeeled tubers, leaves and tender stems.

This cassava plant meal is composed of unpeeled tuber mixed with tender stems and leaves, which led to reduction in cassava flour content of the diets. This new innovation led to the production of fibrous cassava feedstuffs.

A major concern has been raised in food-animal systems about the use of antimicrobials and its effectiveness in human disease control. The 

Humid Tropics

emergence of drug resistant microbial populations in humans and animals and the potential for cross-contamination between populations have resulted in public health officials widely requesting for a sharp reduction of promoting antibacterial in food animals [6]. As a result of this, naturally chemotherapeutic agents are being considered by animal nutritionists as feed additives. One of such agent is zinc oxide $(\mathrm{ZnO})$. Zinc is one of the essential trace elements for prokaryotic and eukaryotic cellular functions, acting as a component of a range of enzymes such as alkaline phosphatases [7]. Although, the promoting growth ability of $\mathrm{ZnO}$ has not been fully established [8], but the antibacterial properties may explain the promoting growth effect.

The need to increase the efficiency of using cassava plant meal with $\mathrm{ZnO}$ as feed additive as a basal diet for pigs led to this study. Hence, the objective of this study was to evaluate the supplemental effects of $\mathrm{ZnO}$ on the utilization of cassava plant meal by growing pigs in the tropics.

\section{Materials and Methods}

The study was carried out at the Swine Unit of the Teaching and Research Farm, Obafemi Awolowo University, Ile-Ife, Osun State, Nigeria.

Cassava leaves and tender stems $(2 \mathrm{~cm}$ to the tip of cassava plant) were collected from the cassava plot at the Obafemi Awolowo University Teaching and Research Farm. They were spread out on a concrete floor open to the air for sun drying. They were turned regularly for even drying, after which they were separately ground. The leaves were confirmed dry when they became crisp, i.e., easy to crumble within the palms; and the tender stems when easily broken without bending. The leaves were sun-dried for about $2 \mathrm{~d}$ depending on the intensity of the sunlight, while the tender stems took about 4-6 d. Cassava tubers were also collected, chopped, spread out on a concrete floor for sun drying and were also turned to allow even drying. The drying was done to about $10 \%$ moisture content for about 5-7 d depending on the intensity of the sun light. After drying, they were also milled. The leaves and the tender stems were mixed together in the ratio 5:1. To make the cassava plant meal sun-dried, unpeeled cassava tuber was mixed with the leaves and tender stems in the ratio 2.5:1.

The gross composition of the experimental diets is shown in Table 1. The diets contained $\mathrm{ZnO}$ in variable proportions.

Four experimental diets were formulated with control diet (without $\mathrm{ZnO}$ ) as diet 1 and $\mathrm{ZnO}$ was added to the diets in three graded levels of 125,250 and $300 \mathrm{ppm}$. All other components of the feed were essentially the same.

Sixteen pigs (Large white $\times$ Hampshire) were used in

Table 1 Gross composition of experimental diet.

\begin{tabular}{|c|c|c|c|c|}
\hline \multirow{2}{*}{ Ingredients (\%) } & \multicolumn{4}{|c|}{ Experimental diets } \\
\hline & 1 & 2 & 3 & 4 \\
\hline Cassava plant meal & 40.00 & 40.00 & 40.00 & 40.00 \\
\hline Ground nut cake & 18.00 & 18.00 & 18.00 & 18.00 \\
\hline Palm kernel cake & 35.00 & 35.00 & 35.00 & 35.00 \\
\hline Fish meal & 2.00 & 2.00 & 2.00 & 2.00 \\
\hline Bone meal & 1.50 & 1.50 & 1.50 & 1.50 \\
\hline Oyster shell & 3.00 & 3.00 & 3.00 & 3.00 \\
\hline$*$ Premix & 0.25 & 0.25 & 0.25 & 0.25 \\
\hline Salt & 0.25 & 0.25 & 0.25 & 0.25 \\
\hline $\mathrm{ZnO}$ (ppm) & - & 125 & 250 & 300 \\
\hline Total & 100 & 100 & 100 & 100 \\
\hline
\end{tabular}


the study. They were distributed into four dietary treatments in a completely randomized design. There were four pigs per dietary treatment and each treatment had two replicates with two pigs per replicate. Pigs in each dietary treatment were fed $4 \%$ of their body weight throughout the period of the experiment, which lasted for eight weeks. Pigs were fed once daily and water was given ad libitum. All routine medication and management practices were carried out accordingly.

The following growth performance parameters were measured and recorded during the experiment: daily feed intake per animal, weight of the animal every day and feed/gain ratio.

At the end of the experiment, blood samples were taken to the laboratory for analysis of various haematological indices, such as white blood cell (WBC), packed cell volume (PCV), red blood cell (RBC) and haemoglobin (HB), using methods outlined by Kelly [9]. The blood samples in the tubes for biochemical assays were allowed to clot before being centrifuged to obtain serum, which was used in the determination of some serum metabolites by standard chemical procedures.

Chemical analysis of the proximate fraction of the feed was carried out as described by Association of Official Analytical Chemists [10]. The data obtained in the experiment were subjected to one way analysis of variance using Statistical Analysis Software [11].

\section{Results and Discussion}

\subsection{The Proximate Composition of the Experimental} Diets

The proximate composition of the experimental diets is shown in Table 2. The dry matter ranged from $92.00 \%$ to $92.82 \%$. Diet 1 with $0 \mathrm{ppm}$ of $\mathrm{ZnO}$ had the highest value, while diet 4 with $300 \mathrm{ppm}$ of $\mathrm{ZnO}$ had the lowest value. The crude protein was the highest $(18.10 \%)$ in diet 2 with $150 \mathrm{ppm}$ of $\mathrm{ZnO}$ and the lowest (17.99\%) in diet 3 with $250 \mathrm{ppm}$ of $\mathrm{ZnO}$. The crude fibre was the highest (14.88\%) in diet 1 with $0 \mathrm{ppm}$ of $\mathrm{ZnO}$, while the lowest value $(9.40 \%)$ was found in diet 3 with $250 \mathrm{ppm}$ of $\mathrm{ZnO}$. The ether extract was the lowest $(1.57 \%)$ in diet 1 with $0 \mathrm{ppm}$ of $\mathrm{ZnO}$, while the higher values occurred with the $\mathrm{ZnO}$ based diets. The nitrogen free extract was the lowest $(50.91 \%)$ in diet 1 with $0 \mathrm{ppm}$ and the highest (54.94\%) in diet 3 with 250 ppm of $\mathrm{ZnO}$. The inclusion of $\mathrm{ZnO}$ in cassava plant meal based diets in this study appeared to reduce crude fibre and increase ether extract and nitrogen free extract of the diets, most importantly when included at 250 $\mathrm{ppm}$. This may be due to the ability of $\mathrm{ZnO}$ to break down fibre component of a feedstuff, and thereby brings about improved utilization of diet. According to Jacela et al. [8], the mechanism by which zinc improves growth rate in pigs is still unclear, however it may not be unconnected with its antibacterial properties. But there appears to be lack of scientific evidence to understand the exact mode of action.

\subsection{Growth Performance}

Table 3 showed the performance of the animals fed experimental diets. The final body weight, which though was not significantly affected $(P \geq 0.05)$, ranged from $41.50 \mathrm{~kg}$ in diet 4 which had $300 \mathrm{ppm}$ of $\mathrm{ZnO}$ to $44.17 \mathrm{~kg}$ in diet 1 which had $0 \mathrm{ppm}$ of $\mathrm{ZnO}$. The average daily weight gain, which ranged from

Table 2 Proximate composition of the experimental diets.

\begin{tabular}{lllll}
\hline \multirow{2}{*}{ Parameters (\%) } & \multicolumn{3}{c}{ Diets } \\
\cline { 2 - 5 } & 1 & 2 & 3 & 4 \\
\hline Dry matter & 92.82 & 92.68 & 92.78 & 92.00 \\
Ash & 7.39 & 9.41 & 8.70 & 8.16 \\
Crude protein & 18.07 & 18.10 & 17.99 & 18.05 \\
Crude fibre & 14.88 & 10.67 & 9.40 & 11.28 \\
Ether extract & 1.57 & 1.76 & 1.75 & 1.76 \\
Nitrogen free extract & 50.91 & 52.74 & 54.94 & 52.75 \\
\hline
\end{tabular}



Humid Tropics

Table 3 Performance of the animals fed experimental diets.

\begin{tabular}{lllllll}
\hline Parameters & \multicolumn{7}{c}{ Diets } \\
\cline { 2 - 6 } & 1 & 2 & 3 & 4 & Pooled ( \pm SEM) & $P$ \\
\hline Initial body weight (kg) & 25.33 & 24.67 & 24.00 & 25.67 & 0.22 & 0.008 \\
Final body weight (kg) & 44.17 & 41.70 & 44.00 & 41.50 & 0.58 & 0.20 \\
Feed intake (kg/day) & $1.18^{\mathrm{a}}$ & $1.11^{\mathrm{b}}$ & $1.13^{\mathrm{b}}$ & $1.11^{\mathrm{b}}$ & 0.06 & 0.001 \\
Weight gain (kg/day) & 0.34 & 0.30 & 0.36 & 0.28 & 0.108 & 0.28 \\
Feed/gain ratio & 3.56 & 3.66 & 3.26 & 4.03 & 0.15 & 0.38 \\
\hline
\end{tabular}

${ }^{\mathrm{a}, \mathrm{b}}$ Means the same row with different superscript differs significantly at $P<0.05$. SEM: standard error of means.

$0.28 \mathrm{~kg}$ in diet 4 with $300 \mathrm{ppm}$ of $\mathrm{ZnO}$ to $0.36 \mathrm{~kg}$ in diet 3 with $250 \mathrm{ppm}$ of $\mathrm{ZnO}$, was not significantly $(P>0.05)$ influenced by the dietary treatment. The daily feed intake, which was though significantly $(P<$ 0.05 ) influenced by dietary treatments, was the lowest in diet $2(1.11 \mathrm{~kg})$ with $150 \mathrm{ppm}$ of $\mathrm{ZnO}$ and the highest in diet $1(1.18 \mathrm{~kg})$ with $0 \mathrm{ppm}$ of $\mathrm{ZnO}$. The inclusion of $\mathrm{ZnO}$ on cassava plant meal based diet appeared to have led to the reduction in feed intake of the animal. This may be due to the ability of $\mathrm{ZnO}$ to bring about reduction in the bulkiness of feed.

The $\mathrm{ZnO}$ appeared to have acted on the fibre component of cassava plant meal and thus bring about reduction in crude fibre. The feed/gain ratio was the lowest in diet 3 (3.26), while diet 4 had the highest value (4.03). The highest weight gain and best feed efficiency in diet 3 may be due to the promoting growth ability of $\mathrm{ZnO}$ [6], which appeared to have been noticed when $\mathrm{ZnO}$ was used at $250 \mathrm{ppm}$ on cassava plant meal.

\subsection{Serum Metabolites}

Table 4 showed the serum metabolites of the animals fed experimental diets. The total serum protein ranged from $60.33 \mathrm{~g} / \mathrm{L}$ to $73.00 \mathrm{~g} / \mathrm{L}$. The highest value occurred significantly $(P \geq 0.05)$ in diet 3 with 250 ppm $\mathrm{ZnO}$, while the lowest value occurred in diet 2 with $150 \mathrm{ppm} \mathrm{ZnO}$. The urea level was the lowest in diet $4(4.03 \mathrm{mmol} / \mathrm{L})$, while diet 1 had 6.0 $\mathrm{mmol} / \mathrm{L}(P>0.05)$. The creatinine of the experimental animal, which was significantly influenced by the experimental diets $(P<0.05)$, was the highest in diet 3
$(194.67 \mathrm{mmol} / \mathrm{L})$ and the lowest in diet 1 (129.20 $\mathrm{mmol} / \mathrm{L})$. The cholesterol of the experimental animals was not significantly affected $(P>0.05)$ by the experimental diets. The lowest value occurred in diet $2(2.60 \mathrm{mmol} / \mathrm{L})$ and the highest value occurred in diet $3(3.20 \mathrm{mmol} / \mathrm{L})$. The serum glucose was significantly affected $(P>0.05)$ by the dietary treatments. The lowest value occurred in diet $4(3.167 \mathrm{mmol} / \mathrm{L})$, while the highest value occurred in diet $2(4.73 \mathrm{mmol} / \mathrm{L})$. The non significant $(P>0.05)$ effect of the dietary treatments on the serum metabolites of the experimental animals may as a result of adequacy of dietary protein and energy in the experimental diets [5]. The significantly $(P<0.05)$ higher values of creatinine with the inclusion of $\mathrm{ZnO}$ in the diets may be due to increased tissue protein degradation and muscular wastage [12].

\subsection{Haematological Indices}

Table 5 showed the haematological indices of the experimental animals. The PCV which ranged from $42.67 \%$ to $47.05 \%$ was not significantly affected $(P>$ $0.05)$ by the dietary treatment. The PCV reduced with increasing levels of $\mathrm{ZnO}$ in the diet. This may indicate the possibility that very high level of $\mathrm{ZnO}$ causes anaemia in growing pigs. The HB of the experimental animal was not significantly $(P>0.05)$ affected by $\mathrm{ZnO}$ supplementation. However, it appeared that the inclusion of $\mathrm{ZnO}$ in the diets of the experimental animals led to reduction in $\mathrm{HB}$ concentration in the blood. However, all the values obtained were within the range recommended for healthy pigs by Duke [13]. 
Table 4 Serum metabolites concentration of experimental animals.

\begin{tabular}{lllllll}
\hline \multirow{2}{*}{ Parameters } & \multicolumn{6}{c}{ Diets } \\
\cline { 2 - 7 } & 1 & 2 & 3 & 4 & Pooled ( \pm SEM) & $P$ \\
\hline Total protein (g/L) & 65.67 & 60.33 & 70.33 & 69.33 & 2.29 & 0.26 \\
Albumin (g/L) & 42.89 & 38.67 & 33.67 & 35.33 & 1.56 & 0.15 \\
Urea (mmol/L) & 6.00 & 4.20 & 4.20 & 4.03 & 0.31 & 0.05 \\
Creatinine (mmol/L) & $129.20^{\mathrm{c}}$ & $159.55^{\mathrm{b}}$ & $194.67^{\mathrm{a}}$ & $177.50^{\mathrm{a}}$ & 8.81 & 0.001 \\
Cholesterol (mmol/L) & 3.10 & 2.60 & 3.20 & 2.87 & 1.51 & 0.55 \\
Glucose (mmol/L) & $4.30^{\mathrm{ab}}$ & $4.60^{\mathrm{ab}}$ & $4.73^{\mathrm{a}}$ & $3.17^{\mathrm{b}}$ & 0.26 & 0.12 \\
\hline
\end{tabular}

${ }^{\mathrm{a}, \mathrm{b}, \mathrm{c}}$ Means the same row with different superscript differs significantly at $P<0.05$. SEM: standard error of means.

Table 5 Haematological indices of the experimental animals.

\begin{tabular}{llllll}
\hline Parameters & \multicolumn{5}{c}{ Diets } \\
\cline { 2 - 6 } & 1 & 2 & 3 & 4 & \pm SEM \\
\hline PCV $(\%)$ & 47.05 & 46.17 & 45.60 & 42.67 & 0.85 \\
$\mathrm{HB}(\mathrm{g} / 100 \mathrm{~mL})$ & 13.50 & 13.30 & 13.43 & 12.27 & 0.25 \\
$\mathrm{RBC}\left(\times 10^{6} / \mu \mathrm{L}\right)$ & 6.70 & 7.20 & 6.80 & 6.40 & 0.14 \\
$\mathrm{WBC}\left(\times 10^{3} / \mu \mathrm{L}\right)$ & $13.90^{\mathrm{ab}}$ & $16.17^{\mathrm{a}}$ & $8.67^{\mathrm{c}}$ & $11.30^{\mathrm{bc}}$ & 1.04 \\
\hline
\end{tabular}

${ }_{\mathrm{a}, \mathrm{b}, \mathrm{c}}$ Means the same row with different superscript differs significantly at $P<0.05$. SEM: standard error of means.

\section{Conclusions}

It can be concluded from this study that $\mathrm{ZnO}$ could be used at $250 \mathrm{ppm}$ as an additive to improve the utilization of cassava plant meal by growing pigs for growth, but for blood parameters, such as heamatology and serum metabolites, the inclusion of $\mathrm{ZnO}$ at level above $250 \mathrm{ppm}$ did not have any deleterious effect.

\section{Acknowledgments}

The author wishes to acknowledge the financial support of the University Research Committee of Obafemi Awolowo University, Ile- Ife, Nigeria.

\section{References}

[1] Iyayi, E. A., and Tewe, O. O. 1994. "Cassava Feeding in Small Holder Livestock Units.” ACTA Holticulturae 375: 261-9.

[2] Ravindran, V. 1990. "Feeding Value and Digestibility of Cassava Leaf Meal for Growing Pigs." In Proceedings of the 5th Australian Animal Production Congress, 20.

[3] Tewe, O. O., and Oke, O. L. 1983. "Performance, Carcass Characteristics and Economy of Production of Growing Pigs on Varying Dietary Cassava Peel Levels." Nutrition Report International 28 (2): 235-43.

[4] Akinfala, E. O., and Matanmi, O. 2011. "Sustainable Utilization of Cassava Plant for Feeding Monogastric
Animals." Presented at 2011 Tropentag Conference Held at the University of Bonn, Bonn, Germany.

[5] Akinfala, E. O., Adegbaju, S. W., and Ilori, J. O. 2013. "Evaluation of the Nutritive Value of Whole Cassava Plant Meal as a Replacement for Maize in the Diets of Growing Pigs in the Tropics." Ife Journal of Agriculture 26: $15-22$.

[6] Mckean, J. 2010. "Feed Additives for Swine." Iowa State University. Accessed December 7, 2012. www.pork.org.

[7] Blencowe, D. K., and Morby, A. P. 2003. "Zn (II) Metabolism in Prokaryotes." FEMS Microbiology Review 27 (2-3): 291-311.

[8] Jacela, J. Y., DeRounchey, J. M., Tokach, M. D., Goodband, R. D., Nelssen, J. L., Renter, D. G., and Dritz, S. S. 2010. "Feed Additives for Swine: Fact Sheets-High Dietary Levels of Copper and Zinc for Young Pigs and Phytase." Journal of Swine Health and Production 18 (2): 87-91.

[9] Kelly, W. R. 1979. Veterinary Clinical Diagnosis, 2nd ed.. London: Baillba Tindall, 266-76.

[10] Association of Official Analytical Chemists (AOAC). 1995. Official Methods of Analysis, 16th ed.. Washington, D.C.: AOAC.

[11] Statistical Analysis Software (SAS). 2000. SAS/STAT Users' Guide (Release 6.03). Cary, NC: SAS Inst. Inc..

[12] Fanimo, D. A. 1991. "Substitution of Soya Bean Meal and Animal by-Product for Fish Meal in Pigs Ration." Ph.D. thesis, University of Ibadan, Ibadan, Nigeria.

[13] Duke, H. H. 1975. Duke's Physiology of Domestic Animals, 8th ed.. Ithaca and London: Cowstock Publishing Associates. 